\title{
ALICE IN RANDOMLAND: A RESOURCE FOR IMPROVING ATTITUDES TOWARDS PROBABILITY AND ITS TEACHING
}

\author{
FLAVIO GUIÑEZ \\ Universidad de Chile \\ flavioguinez@uchile.cl \\ CLAUDIA VÁSQUEZ \\ Pontificia Universidad Católica de Chile \\ cavasque@uc.cl \\ CAMILA BRITO \\ Universidad de Chile \\ camila.brito@uchile.cl \\ SALOMÉ MARTÍNEZ \\ Universidad de Chile \\ samartin@dim.uchile.cl
}

\begin{abstract}
This article presents the results of a study aimed at examining how primary school teachers' attitudes towards probability and its teaching are influenced by their use of an interactive story focused on sparking interest in probability and providing opportunities for learning this mathematical topic. A scale of attitudes towards probability and its teaching was applied to 40 prospective primary school teachers, before and after reading the book. This instrument was implemented with two focus groups. Preliminary results revealed significant changes in pre-service teachers' attitudes, particularly in their feelings towards probability. This evidence attested to the potential of the book, especially considering that the participants had only studied the basics of this topic in previous courses.
\end{abstract}

Keywords: Statistics education research; Probability; Attitudes; Pre-service teacher education; Educational resources; Context based problem-solving

\section{INTRODUCTION}

The teaching of probability in schools has gained relevance for decades as a result of its usefulness and applicability in multiple fields of knowledge (Scheaffer et al., 1998). In addition, learning about probability can help the development of critical thinking (Everitt, 1999) and - most of all—it "provides an excellent opportunity for showing students how to mathematize, that is, how to use mathematics to solve real problems" (Godino et al., 1997, p. 12). The inclusion of probability in the school curriculum provides contexts, problems, and tools that support children's development of probability literacy, which is needed "to cope with a wide range of real-world situations that involve interpretation or generation of probabilistic messages as well as decision-making" (Gal, 2005, p. 45).

In Chile, the current curricular guidelines for Primary School Education (MINEDUC, 2012) indicate that all students (6 to 13 years old) "must begin to study topics related to probability" (p. 5). This poses great challenges for the teachers who need to implement the curriculum, because many of them have received no disciplinary or didactic training in probability (MINEDUC, 2016). Therefore, many of them lack the necessary knowledge (Vásquez, 2014) and feel unprepared to cover these topics (Groth \& Meletiou-Mavrotheris, 2018).

The success of these curricular guidelines depends not only on teachers' disciplinary and didactic knowledge, but also on their interest in these topics and their willingness to teach them, two aspects that Batanero (2013) regards as fundamental for students to develop a positive attitude towards learning probability. Thus, according to Veloo and Chairhany (2013), initial teacher education programs must 
explore future teachers' attitudes towards these topics, so that teacher educators can use this information to develop strategies that enable them to have a positive impact on students' attitudes.

In this study, we will define an attitude as "a mental construct that is not directly observable, but which must be inferred through an assessment informed by an attitude scale or the observation of subjects' behavior" (Batanero, 2009, p. 6). From this perspective, we will analyze how prospective primary school teachers' attitudes towards probability and its teaching are influenced by their interactions with the book Alice in Randomland (Brito et al., 2018). Inspired by characters and elements from Lewis Carroll's classic book, Alice's Adventures in Wonderland (1865), this interactive story is aimed at stimulating readers' interest in probability and provides opportunities for learning about this topic. The research question guiding this study is whether reading of Alice in Randomland has an impact on the prospective teachers' attitudes towards probability and its teaching. To do this, we conducted an intervention with 40 prospective primary school teachers in a Mathematics teaching methods course, which included reading Alice in Randomland and interacting with its mobile application. We administered the Attitudes Scale Towards Probability and Its Teaching, created by Estrada and Batanero (2015), at the pre- and post-test stage. After the intervention, a focus group was conducted in order to complement the information produced with the attitudes scale, explore possible changes, and to reveal students' views on their experience during the intervention.

In the following sections, we describe the theoretical framework that underlies the Attitudes Scale Towards Probability and Its Teaching, Alice in Randomland, and the teaching sequence proposed by the book. Then, we detail the methodology used in the intervention, the characteristics of the sample, and the analysis procedures. Finally, we present the results, discussing the evidence that makes it possible to evaluate the potential of this resource as a tool for promoting a positive attitude towards probability and its teaching among other cohorts of teachers.

\section{ATTITUDES TOWARDS PROBABILITY AND ITS TEACHING}

Attitudes are a key element when learning mathematics, since they influence a student's behavior in relation to the discipline. Positive or negative school experiences might affect them, but they could also be transferred from one person to another. Therefore, exploring teachers' attitudes towards mathematics is essential, and especially with respect to topics like statistics and probability with which they are less familiar (Estrada et al., 2011; Veloo \& Chairhany, 2013). Indeed, the enactment of the recent curricular reforms on these areas not only depends on teachers' preparation, but also on their willingness and interest to teach them (Estrada et al., 2018).

Research on teachers' attitudes has expanded over the last few decades, covering topics such as attitudes towards mathematics (Barrientos, 2010; Klinger, 2011; Schoenfeld, 1989) and attitudes towards statistics (Estrada, 2002; Estrada et al., 2013; Ordoñez et al., 2016). Although several instruments have been used to evaluate attitudes towards mathematics (Auzmendi, 1992; Klinger, 2011; Schoenfeld, 1989), those used to assess probability are less numerous. Of relevance is a pioneering study conducted by Estrada and Batanero (2015) from which they proposed a three-dimensional model with seven components for analyzing attitudes towards probability and its teaching (see Table 1). Based on this model, Estrada et al. (2018) constructed and validated a scale to measure teachers' attitudes towards probability and its teaching. The questionnaire was applied to 232 prospective primary school teachers and the results suggest a generally positive attitude towards probability and its teaching. Findings showed the scale is adequately reliable (Cronbach's alpha $=0.89$ ) and explains $67.9 \%$ of the model's variance based on its seven factors. The scale, Attitudes Scale Towards Probability and Its Teaching, is used in this study. 
Table 1. Dimensions and components of teachers' attitudes towards probability and its teaching (Estrada \& Batanero, 2015).

\begin{tabular}{|c|c|c|}
\hline Attitudes towards probability & $\begin{array}{l}\text { Attitudes towards the teaching of } \\
\text { probability }\end{array}$ & $\begin{array}{c}\text { Appreciation of the contents and } \\
\text { their teaching }\end{array}$ \\
\hline $\begin{array}{l}\text { 1. Affective component towards } \\
\text { probability (AP): Feelings about } \\
\text { probability. }\end{array}$ & $\begin{array}{l}\text { 4. Affective component towards } \\
\text { teaching probability (AT): } \\
\text { Personal feelings about teaching } \\
\text { probability, which may differ } \\
\text { from (although may be associated } \\
\text { with) feelings towards the topic } \\
\text { itself: pleasure-displeasure, fear- } \\
\text { confidence, interest-disinterest in } \\
\text { teaching probability. }\end{array}$ & $\begin{array}{l}\text { 7. Value component towards } \\
\text { probability and its } \\
\text { teaching (VPT): appreciation of } \\
\text { the usefulness, relevance, and } \\
\text { importance of probability and its } \\
\text { teaching in personal and } \\
\text { professional life. }\end{array}$ \\
\hline $\begin{array}{l}\text { 2. Cognitive competence } \\
\text { towards probability (CCP): } \\
\text { Self-perception with regards to } \\
\text { self-competence, knowledge, } \\
\text { and intellectual skills when } \\
\text { applied to probability. }\end{array}$ & $\begin{array}{l}\text { 5. Teaching probability } \\
\text { competence component }(\mathrm{CT}) \text { : } \\
\text { This component assesses the } \\
\text { teacher's perception of his/her } \\
\text { ability to teach probability, to } \\
\text { help students, to pose effective } \\
\text { tasks to seek relevant resources, } \\
\text { etc. }\end{array}$ & \\
\hline $\begin{array}{l}\text { 3. Behavioral component } \\
\text { towards probability (BP): } \\
\text { Inclinations to act towards the } \\
\text { attitude object in a particular } \\
\text { way, to make decisions in } \\
\text { situations involving the attitude } \\
\text { object, to help colleagues to } \\
\text { learn and use probability. }\end{array}$ & $\begin{array}{l}\text { 6. Behavioral component towards } \\
\text { teaching probability (BT): This } \\
\text { component is related to didactic } \\
\text { action: whether the teacher has or } \\
\text { has not taught (or whether he/she } \\
\text { is willing or not willing to teach) } \\
\text { probability, whether he/she gives } \\
\text { priority to probability over other } \\
\text { topics, and whether he/she thinks } \\
\text { the topic should be postponed or } \\
\text { given emphasis. }\end{array}$ & \\
\hline
\end{tabular}

A new application of the instrument to 416 prospective primary school teachers in Spain by the same research team (Estrada \& Batanero, 2020) showed similar results, with all the components of the scale scoring an average and median well above the theoretical mean. In Chile, Alvarado et al. (2018) using the same scale, analyzed attitudes towards probability and its teaching in 70 in-service secondary school Mathematics teachers and 51 pre-service secondary school Mathematics teachers. Overall, they found teachers have a positive attitude towards probability and its teaching, with in-service teachers with classroom experience being slightly more positive. Vásquez et al. (2019), analyzed the attitudes towards probability and its teaching of 124 pre-service preschool teachers, using an instrument based on Estrada and Batanero's scale. In that case attitudes were more negative; teachers had low selfperceived knowledge about the topic, even though they appreciated the usefulness and importance of teaching probability.

These results suggest two main directions for future research relevant to the learning and teaching of probability. First, to improve our descriptions and understanding of both in-service and pre-service teachers' attitudes towards the teaching of probability (Estrada et al., 2018). Second, to conduct studies aimed at generating instructional processes that motivate teachers and increase their interest in probability and its teaching, for instance, by using innovative didactic resources. The few available studies on this subject suggest that active learning environments, cooperative games, and tournaments, mediated by the use of technology during the instruction process, contribute to encouraging positive attitudes towards the learning of probability (Tan et al., 2011; Velooo \& Chairhany, 2013). This opens opportunities to enhance teachers' knowledge and attitudes towards teaching probability, and at the same time give them new strategies and methodologies to enhance their teaching practice. 


\section{DESCRIPTION OF ALICE IN RANDOMLAND}

Alice in Randomland (Brito et al., 2018) is an interactive story created by a team of teachers and researchers from a mathematics research center with the aim to increase motivation and interest in probability among students aged 11-13. To do this, they used a narrative that combines mathematical brainteasers with a fantasy world inspired by Lewis Carroll's classic, Alice in Wonderland. Alice in Randomland is a genuine mathematical story, that is, the mathematical ideas in it are essential for setting the scene and for the advancement of the plot (Borasi et al., 1990). The book includes ideas that are fundamental for developing probabilistic and stochastic thinking (Borovcnik, 1997; Heitele, 1975), which are introduced, for instance, by using paradigmatic examples as described in Borovcnik (2006). The book includes a complementary mobile application, which readers can use to simulate results, and also for analyzing related problems, applying and extending the strategies presented in the book. The illustrations included not only give life to the characters and magical settings, but also support the visualization of mathematical ideas. They are used to represent mathematical strategies and problemsolving procedures, which means that the story has potential as a teaching and learning tool, particularly regarding the use of representations.

The story is divided into chapters, each introducing a challenge that the protagonist must overcome by either playing or analyzing a game of chance focused on a fundamental idea of probability. The first two chapters present random experiments that involve card and dice games that are analyzed through the frequency-based and the empirical notions of probability. In one of them, Alice and The Hatter play a card game that she can win if she picks two cards of the same color from a hat with two red cards and a blue one (Figure 1). Even though the game has only two results it is not symmetrical, and thus it triggers a misconception: both possible results have the same likelihood of occurring. This common misconception is known in literature as the equiprobability bias, and it is described as a tendency for individuals to believe that any random outcomes share the same probability (Lecoutre, 1992). In the story, a magical clock starts running, accelerating time, which leads the characters to play the game very fast (Figure 1). After numerous repetitions, The Hatter says he knew what would eventually happen because he had played the game many times, thus introducing a fundamental idea of the empirical approach to probability. For this game, the mobile app includes a simulation of the experiment that dynamically shows the outcomes, thus enabling readers to contrast their initial beliefs with the empirical results obtained in a large number of repetitions.
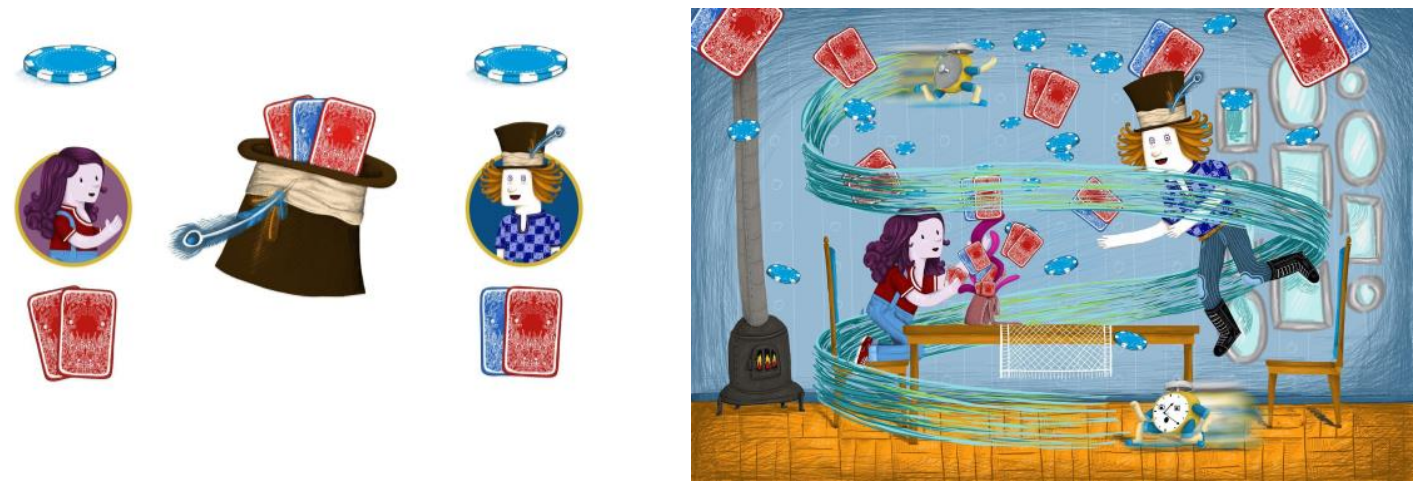

Figure 1: The card game between Alice and the Hatter, which addresses fundamental ideas about the empirical approach to probability.

Once the protagonist has had her first experiences with games of chance, she encounters new challenges that require her to analyze the possible outcomes of random experiments without simulation. To do this, Alice will discover and create representations and heuristics that will make it easier for her to find and analyze possible cases of random experiments. Thus, readers are exposed to the classical notion of probability through problems that involve combinatorial reasoning, motivating the development of basic counting strategies. For instance, in Chapter 3, a dice game is presented in which the twins Lilo and Lila, are betting on the occurrence of equally probable events (Figure 2). The app 
includes a variant of this game that enables users to not only simulate the results of the new game, but also analyze the results through representations that facilitate the development of counting strategies.
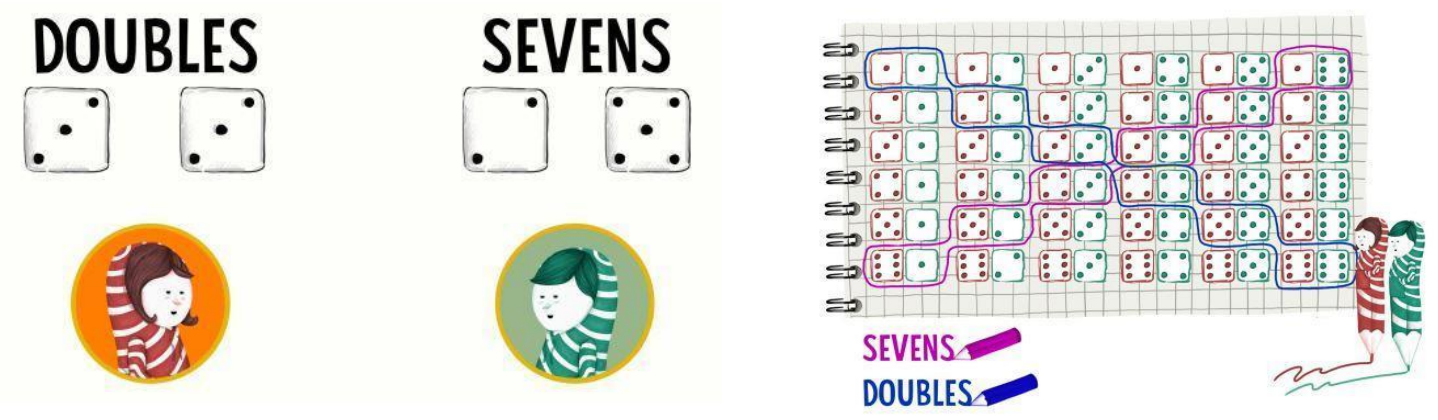

Figure 2: The dice game of the twins that leads Alice to explore initial ideas of the classic approach to probability.

The last chapters highlight the complementary nature of the classical and the empirical approaches. They present situations in which readers can observe how the analysis of possible cases explains empirical outcomes that may be initially counterintuitive. In addition, the protagonist tackles problems by analyzing possible cases, which makes it possible to anticipate the results of a game when the associated random experiment is repeated several times.

\section{METHODOLOGY}

For this study we used a mixed methodology approach. Regarding the quantitative component, a pre-experimental design was adopted that comprised of the administration of a pre- and a post-test to a single group (Hernández et al., 2002). Its purpose was to measure changes in participants' attitudes as a result of the intervention. This was complemented with a qualitative phenomenological component that consisted of focus groups aimed at finding out how students experienced the intervention (Cohen et al., 2000). This research approach allows a more comprehensive understanding of the phenomenon under study.

\subsection{SAMPLE}

The non-probabilistic sample used comprises 40 prospective primary school teachers ( 15 men and 25 women) of a Chilean teacher education program. They had all passed a content focused course on basic statistics and probability and were enrolled in a Mathematics teaching method course while participating in the study. At the beginning of the course, the participants were informed of the characteristics of the study and the confidential nature of their responses. All of them took part in the intervention voluntarily and signed a consent form.

\subsection{INSTRUMENTS}

In the quantitative study, we administered the Attitudes Scale Towards Probability and Its Teaching, proposed by Estrada et al. (2018) and included in the Appendix. As mentioned above, this instrument measures seven components of teachers' attitudes towards probability and its teaching (Table 2) and comprises 28 items that employ a five-point Likert scale (1: strongly disagree, 2: disagree, 3: neither agree nor disagree, 4: disagree, and 5: strongly agree). 
Table 2. Components of teachers' attitudes towards probability and its teaching that were evaluated

\begin{tabular}{ll}
\hline \multicolumn{1}{c}{ Components } & \multicolumn{1}{c}{ Items } \\
\hline Affective Component Towards Probability (AP) & $1,5,16,27$ \\
Cognitive Competence Towards Probability (CCP) & $6,8,17,22$ \\
Behavioral Component Towards Probability (BP) & $2,7,15,18$ \\
Affective Component Towards Teaching Probability (AT) & $9,21,26,28$ \\
Teaching Probability Competence Component (CT) & $3,10,14,23$ \\
Behavioral Component Towards Teaching Probability (BT) & $11,20,24,25$ \\
Value Component Towards Probability and Its Teaching (VPT) & $4,12,13,19$ \\
\hline
\end{tabular}

In order to avoid the acquiescence bias of respondents (Morales, 1988), 14 of the 28 items were worded positively $(1,2,4,5,6,8,9,10,14,15,19,20,24,28)$, while 14 were worded negatively $(3,7$, $11,12,13,16,17,18,21,22,23,25,26,27)$. To analyze the results, we inverted the scores for the negative items, thus generating a homogeneous scale for comparison. As a consequence, a relatively high mean always indicates a relatively high positive attitude, regardless of whether the item is worded positively or negatively.

For the qualitative study, we used focus groups because they encourage interaction and discussion among participants, thus contributing to the exchange of ideas, opinions, and reflections (Kidd \& Parshall, 2000). Two focus groups were set up, both of which were led by one researcher. These groups were organized around a set of questions aimed at exploring participants' views on the characteristics of Alice in Randomland (narrative, illustrations, and apps), changes in their perception of probability and its teaching, and their opinions regarding the possible use of the book in schools. Both focus groups were video-recorded, and the audio data were transcribed for analysis.

\subsection{INTERVENTION}

In order to detect changes in future teachers' attitudes towards probability after interacting with Alice in Randomland, we conducted the intervention with students enrolled in a Mathematics teaching method course in the first semester of 2019, whose last unit was devoted to the teaching of probability in primary school education. The Attitudes Scale Towards Probability and Its Teaching was administered as a pre-test at the beginning of the semester. Then, each student received a copy of the interactive story and had three weeks to read it and interact with the app individually. After this period, the same attitudes scale instrument was administered as a post-test. The focus groups were set up a couple of weeks later. It is worth noting that the intervention ended before the start of the probability unit; therefore, no interference was expected in the evolution of the attitude towards probability and its teaching.

\subsection{ANALYSIS PROCEDURES}

The results of the Attitudes Scale Towards Probability and Its Teaching were measured before and after the intervention. Descriptive analyses and inferential methods were used to detect significant differences between averages. To do this and to detect attitudinal changes, Student's t-test for paired samples was applied to each of the scale's components. Student's t-test checked the null hypothesis that the difference between the pre- and the post-test means was zero, also testing the alternative hypothesis that the difference was negative, which would indicate a higher post-test value with respect to pre-test components. Results are reported with $95 \%$ confidence, that is, those components whose $p$-value on the test is lower than 0.05 .

The analysis of the focus groups sought to define categories based on the unprocessed data, within a framework that captured key topics that the researchers deemed to be important in connection with the two components of the scale that displayed the greatest changes in the quantitative study. The process started with a thematic analysis (Braun \& Clarke, 2006), with two researchers reading the data multiple times to identify recurrent topics. Then, quotations were labeled with initial codes related to: (a) the two components of the scale: Affective Component Towards Probability (AP) and/or Affective 
Component Towards Teaching Probability (AT); and (b) the emotions expressed by the participants, such as boredom, comfort, interest, enjoyment, concern, or fear. Based on this initial coding, emergent categories were established using a Constant Comparative Method (Strauss \& Corbin, 2007), which are described in Table 3. A first category that emerged was related to students' school experiences associated with the learning of probability. Other quotations were grouped according to evidence of changes in their perceptions as a result of their interaction with the book. This allowed us to define two other categories depending on whether these changes expressed feelings about either the learning or the teaching of probability.

Table 3. Categories that emerged from the analysis of the focus groups.

\begin{tabular}{|c|c|c|}
\hline Category & Description & Examples of quotations \\
\hline $\begin{array}{l}\text { Prior experiences } \\
\text { with the learning } \\
\text { of probability }\end{array}$ & $\begin{array}{l}\text { Students' perceptions of } \\
\text { the learning of } \\
\text { probability in school } \\
\text { settings }\end{array}$ & $\begin{array}{l}\text { I mean, the resistance to probability is generated in primary } \\
\text { school, because they teach it in a very boring way or too } \\
\text { symbolically. I mean symbolically in a mathematical way, there's } \\
\text { no connection with anything else. (Focus Group } 2 \text {, student } 1 \text { ) }\end{array}$ \\
\hline \multirow[t]{2}{*}{$\begin{array}{l}\text { New perspectives } \\
\text { about probability } \\
\text { and its learning }\end{array}$} & \multirow{2}{*}{$\begin{array}{l}\text { Changes in students' } \\
\text { perceptions about } \\
\text { probability and its } \\
\text { learning as a result of } \\
\text { their interaction with the } \\
\text { book }\end{array}$} & $\begin{array}{l}\text { It caught my attention and also allowed me to understand what } \\
\text { it [the book] sought to convey, the topic of probability, what it } \\
\text { dealt with. (Focus Group } 1 \text {, student } 2 \text { ) }\end{array}$ \\
\hline & & $\begin{array}{l}\text { It was fun to see that with an applied game, maybe I had seen it } \\
\text { more algorithmically, with numbers only, and seeing it as } \\
\text { something more didactic, pictorial, was an interesting twist. } \\
\text { (Focus Group } 2 \text {, student } 8 \text { ) }\end{array}$ \\
\hline \multirow[t]{2}{*}{$\begin{array}{l}\text { New approaches } \\
\text { for teaching } \\
\text { probability }\end{array}$} & \multirow{2}{*}{$\begin{array}{l}\text { Changes in students' } \\
\text { perceptions about the } \\
\text { teaching of probability } \\
\text { and the potential use of } \\
\text { the book as a teaching } \\
\text { resource }\end{array}$} & $\begin{array}{l}\text { You can learn by playing a game, teachers can teach through } \\
\text { games, but it has to be directed through a methodology... so you } \\
\text { can teach children through games. (Focus Group } 1, \text { student } 3 \text { ) }\end{array}$ \\
\hline & & $\begin{array}{l}\text { I would take the book apart. I mean it could start with a single } \\
\text { chapter, the Hatter's; and see how that content contributes to my } \\
\text { methodology, so I can explore how I could teach, because I had } \\
\text { no idea how to teach probability, which I find boring, in a fun } \\
\text { way. (Focus Group } 1 \text {, student } 4 \text { ) }\end{array}$ \\
\hline
\end{tabular}

\section{RESULTS}

The results are grouped into three sections. The first presents a quantitative outline of the students' initial attitudes; the second shows the results of the pre- and post-test administration of the aforementioned instrument; and the third provides a qualitative description of the focus group results.

\subsection{FUTURE PRIMARY SCHOOL TEACHERS' ATTITUDES SCALE TOWARDS PROBABILITY AND ITS TEACHING (PRE-TEST)}

The analysis of the results of the pre-test (Table 4) showed that the highest-scoring components are Affective Component Towards Teaching Probability (AP), with 3.98 points on average on a scale from 1 to 5, followed by Affective Component Towards Probability (AT), with 3.18 points on average. In contrast, the lowest-scoring components on the pre-test, reflecting the participants' negative attitude, are Cognitive Competence Towards Probability (2.71 points) and Behavioral Component Towards Teaching Probability (2.26 points). Both scores are under the theoretical mean of 3 points.

\subsection{PRE- AND POST-TEST COMPARISON}

In order to evaluate the impact of Alice in Randomland on the participants' attitudes scale towards probability and its teaching, the instrument was also administered after the future teachers interacted with the resource. Table 4 shows the results of the application of Student's t-test for paired samples to each component of the scale. Table 4 indicates that AT is the only component that displays a statistically 
significant difference between the pre- and post-test means ( $p$-value $=0.012<0.05)$, which can be interpreted as a positive change, a situation that is not true of the rest of the components.

Table 4. Results of the application of Student's t-test for paired samples to each component of the scale.

\begin{tabular}{|c|c|c|c|c|c|}
\hline & \multicolumn{2}{|c|}{ Pre-test } & \multicolumn{2}{|c|}{ Post-test } & \multirow{2}{*}{$p$-value } \\
\hline & Mean & $S D$ & Mean & $S D$ & \\
\hline $\begin{array}{l}\text { Affective Component Towards } \\
\text { probability (AP) }\end{array}$ & 3.18 & 0.42 & 3.26 & 0.41 & 0.114 \\
\hline $\begin{array}{l}\text { Cognitive Competence Towards } \\
\text { Probability (CCP) }\end{array}$ & 2.71 & 0.39 & 2.73 & 0.36 & 0.441 \\
\hline $\begin{array}{l}\text { Behavioral Component Towards } \\
\text { Probability (BP) }\end{array}$ & 2.99 & 0.39 & 2.99 & 0.36 & 0.5 \\
\hline $\begin{array}{l}\text { Affective Component Towards } \\
\text { Teaching Probability (AT) }\end{array}$ & 3.98 & 0.52 & 4.15 & 0.50 & 0.012 \\
\hline $\begin{array}{l}\text { Teaching Probability Competence } \\
\text { Component (CT) }\end{array}$ & 2.84 & 0.50 & 2.79 & 0.43 & 0.686 \\
\hline $\begin{array}{l}\text { Behavioral Component Towards } \\
\text { Teaching Probability (BT) }\end{array}$ & 2.26 & 0.45 & 2.28 & 0.64 & 0.438 \\
\hline $\begin{array}{l}\text { Value Component Towards Probability } \\
\text { and Its Teaching (VPT) }\end{array}$ & 2.95 & 0.34 & 2.86 & 0.35 & 0.876 \\
\hline
\end{tabular}

Since Student's t-test assumes normal distribution of the data, a normality test (K-S test) was applied to the components to prove this assumption. The K-S test revealed that only the components CT, BT and VPT fit a normal distribution, which means that they can be processed with Student's t-test. Since the component AT did not pass the normality test, it must be processed with a non-parametric test of differences between means. Therefore, in order to add robustness to the data processing, the Wilcoxon signed-rank test was applied. Table 5 shows the results of the application of this test to the component AT. The test presents a $p$-value $=0.022<0.05$ (Table 5). Therefore, it is possible to state with $95 \%$ confidence that the component AT ha a statistically significant difference between its pre- and post-test means

Table 5. Results of the application of the Wilcoxon signed-rank test to the AETP component

\begin{tabular}{lccc}
\hline & $\begin{array}{c}\text { Pre-test } \\
\text { Mean }\end{array}$ & $\begin{array}{c}\text { Post-test } \\
\text { Mean }\end{array}$ & $p$-value \\
\hline $\begin{array}{l}\text { Affective Component Towards Teaching } \\
\text { Probability (AT) }\end{array}$ & 3.18 & 3.26 & 0.022 \\
\hline
\end{tabular}

\subsection{FOCUS GROUP RESULTS}

This section describes the main results of our analysis of the focus groups, which was aimed at exploring students' perceptions and attitudes regarding the components AP and AT. Our analysis of the quotations that refer to affective elements associated with probability and its teaching resulted in three categories: a) Prior experiences with the learning of probability; b) New perspectives on probability and its learning; and c) New approaches for teaching probability (see Table 3 for a description). The following quotations were selected to accurately represent the data collected.

Previous experiences with the learning of probability. Something that drew attention during the analysis of the focus groups is that future teachers perceive their learning experiences in school as decontextualized, focused on abstract aspects, and centered on the teacher and not the learner.

The math we learned was too abstract, teachers only covered the content and didn't really care whether we appropriated probability or not. (Focus Group 2, student 6) 
Besides, they claimed that this traditional approach to teaching was persistent throughout their whole school experience and alienated them from mathematics.

There's this paradigm that math is boring and that it's super strict and rigorous. I have that notion because that's what teachers left me throughout my school education. (Focus Group 2, student 3)

Statements like these recurred during the conversation and, as it is shown below, many of them were used as a means to express how their conceptions about probability and their teaching changed as a result of their interaction with Alice in Randomland.

New perspective on probability and its learning. Most of the participants seemed to regard the book as a novel way of approaching probability, contrasting it with how they learnt it in school. The following quotations illustrate this:

I thought it was a really practical way of explaining something that used to be quite complex for me. (Focus Group 1, student 1)

In contrast, in the past, like in primary school, you were taught everything textually, you had to imagine everything in your mind [...]. You got confused and didn't know what to do. But here everything is more visual, and you can get a clearer view of what probability is and how to handle it, how to use it. (Focus Group 2, student 6)

In fact, this way of addressing a topic that they find difficult appears to be helping to modify their view of mathematics, as described in the next quote:

When you are shown things this way, you can connect math to something real that exists in everyday life, it can even be fun. So, your perspective changes, that paradigm that math is boring and that it's super strict and rigorous. (Focus Group 2, student 3)

Some of the main characteristics of the book that were highlighted by the students and could explain some of the changes they experienced is the use of a well-known story which brings math closer to children and allows identification with the characters and the problems that the protagonist must face. The following extracts evidence this:

I think the approach in this story [...] brings the topic closer to readers and takes us away from boring approaches to math [...]. I felt the book brings math closer to children, from other perspectives. (Focus Group 2, student 3)

I really identified with Alice [...]. Because she tried to work out what happened with the twins, for instance. [...] I think that's what encourages students to never give up and attempt to solve the problems in the way they find most convenient. (Focus Group 2, student 5)

Similarly, some viewed the story as a metaphor of the challenges children must overcome when tackling a topic that differs from the mathematics that they had encountered before, as this quote shows:

I like the fact that it's mystical because it gives you the chance to enter a new world, the world of probability. I mean, when Alice falls into the rabbit hole of probability, readers enter the world of this new content, probability, as they leave the math of addition and subtraction [...] and approach another domain, that of probability. So, it's very interesting, it's like a door to a new world. (Focus Group 2, student 2)

As a student shared, the book also contributed to reorganizing previous ideas and concepts, enabling her to move from a blurred internal image of probability to a more consolidated one.

Rather than change my perceptions or something, it organized my ideas. I had all the concepts in a little cloud, floating around, and then they all jumped to another little cloud, but now they were within a neat scheme. And that helped me organize my ideas about this topic. (Focus Group 1 , student 1)

New approaches for teaching probability. In general terms, the students expressed that reading the book influenced their perspectives about the teaching of probability positively:

I think it really changed my perception. I saw probability as something heavier but now I see it as something I could teach more comfortably, without any uneasiness. (Focus Group 2, student 4) 
Indeed, most of the students shared their willingness and excitement to use the book as a teaching resource, even though it was not presented to them with that purpose:

It's a story you already know, and you see the methodology applied is really simple. I mean, it's not simple, there's an underlying structure, but it's so easy to understand that something really clicks and it's cool. You get really interested in working with this book. I'd be really excited to use it in the classroom. (Focus Group 2, student 8)

This may have to do with some methodological strategies they identified in Alice, presented explicitly or implicitly in the book, that they would rather use instead of those with which they were taught. For example, a future teacher stressed that:

The book starts with Alice at school and her teacher presents an activity, but he doesn't say, "what will happen if I take out this or that?" He [the teacher] makes students do it, like the approach we try to apply nowadays. (Focus Group 1, student 2)

Another participant mentioned the use of characters, even managing to extrapolate this strategy to other contents:

So now at the university, since you're doing this, you get acquainted with other methods, like the book. And you realize you could actually cover any mathematical content using a character, which can bring a topic closer to students and make it easier to understand. (Focus Group 2, student 3)

In contrast, some students imagined themselves using the book in the classroom and were able to put themselves in the shoes of the children whom they must teach as they read it. The following quotations evidence this:

I would take the book apart. I mean it could start with a single chapter, the Hatter's; and see how that content contributes to my methodology, so I can explore how I could teach, because I had no idea how to teach probability, which I find boring, in a fun way. (Focus Group 1, student 4)

It can be really useful for explaining things that children find pretty unfamiliar even though they exist in everyday life [...] there's a contextualization of what children might think, like a classmate said, maybe children don't realize how probabilities operate in the story. But they gradually learn what they are as they read. (Focus Group 2, student 7)

In other words, Alice seems to be helping students start positioning themselves as future teachers, which could explain in part the changes observed in the affective component to the teaching of probability.

\section{DISCUSSION}

This study analyzed changes in the attitudes towards probability and its teaching present in a sample of 40 prospective primary school teachers in Chile as a result of their interaction with the book Alice in Randomland. Pre-test results showed that affective elements associated with the teaching of probability and with probability itself displayed the highest scores among all the components measured (3.98 and 3.18 , respectively). In contrast, the perceived cognitive competence regarding probability and also the behavior competence related to the teaching of probability display the lowest scores (2.71 and 2.26, respectively). Therefore, these results indicated that the participants of the study, despite having positive feelings towards probability and its teaching, had a poor self-perception of their competences, knowledge, and intellectual capabilities regarding probability and its teaching. These findings are similar to those reported by Vásquez and colleagues (2019) with Chilean prospective preschool teachers. This showed that future teachers may perceive themselves as not very competent, and therefore there is a need to improve their sense of self-efficacy and the self-perception of their own capacities.

Due to this and considering the low coverage of topics related to the teaching of probability in the training programs in the country (MINEDUC, 2016), it becomes urgent to organize pedagogical activities to enhance the professional competences of pre-service and in-service teachers in order to equip them with the tools needed to understand and teach probability. It is worth to remark that our results contrast with the findings of studies conducted in Spain (Estrada et al., 2018; Estrada \& Batanero, 2020), which showed that prospective primary school teachers have a generally positive attitude in every component of the scale. As it is proposed in these articles, more comparative studies that explore 
future teachers' attitudes towards probability and its teaching are needed, particularly among Latin American countries.

In addition, the results presented in this study provide evidence for the seemingly positive influence of Alice in Randomland on future teachers' feelings about the teaching of probability. Indeed, a significant change can be observed in this affective component after interacting with the book in the quantitative results, which is consistent with participants' responses in the focus groups. Reading Alice allowed them to contrast the traditional teaching of probability they experienced with this innovative approach, which seems to have motivated them so much to even encourage themselves to replicate it with their future school students. Moreover, affective elements associated with probability, despite not varying to a statistically significant degree, display a positive change, which suggests that the resource may also be affecting this component. This hypothesis is backed by the qualitative analysis of the students' participation in the focus groups, which are indicative of affective changes towards probability.

Students' comments suggested that their prior learning experiences had greatly affected their relationship with probability. Their memories portrayed a traditional teaching approach and a rather abstract way of covering contents, which-they said-made it difficult to appropriate probability and it could explain some of the feelings of unpreparedness for teaching this topic, some reported (Groth \& Meletiou-Mavrotheris, 2018). These results give some clues about the origin of these attitudes, which is one of the lines of research suggested by Estrada and Batanero (2020), and we believe that it is worthwhile to do more qualitative studies to explore how past experiences affect the different components of the scale.

The participants' description of school episodes stands in contrast with their appreciation of the resource, which they regarded as a positive influence that made them think of new approaches and strategies in teaching probability. The participants highlighted the didactic sequence proposed in the book, which they believed will facilitate the learning of probability through a narrative that school students may find accessible, and which may encourage exploration through challenges and the use of visualization (Gal, 2005). It is also interesting to note how the participants identified with the protagonist's journey and how they associated it with the challenges that children encounter when learning probability (Batanero, 2013). This new way of thinking and relating to content may be linked to the results observed in the components associated with feelings towards the teaching of probability, as the evidence revealed an increase in the participants' interest in teaching this topic and a reduction in their worries about performing this task adequately.

The evidence obtained in this exploratory study encourages us to extend and strengthen our results, particularly regarding the impact and the reasons behind changes in future teachers' attitudes towards probability and its teaching after interacting with Alice. To do this, it would be necessary to enlarge and diversify the sample and add a control group to the study design, so that the differences observed between the pre- and post-test stages could be exclusively ascribed to the intervention. At the same time, it might be worth exploring the book as a learning device and if complementary activities that address its use for teaching could lead to improvements in the cognitive and behavioral attitudes of prospective teachers.

In any case, the findings described in this study present the great opportunity of creating learning resources and instruction strategies focused on probability that have an impact on teachers' initial and continuing education. Resources like Alice in Randomland, designed to address fundamental ideas about probability and illustrate innovative teaching approaches, could help to improve their disciplinary and didactic knowledge. At the same time, learning devices based on stories that allow empathizing with the difficulties experienced in the school when learning this topic could be a useful strategy to modify future teachers' attitudes towards probability and lead to new teaching approaches capable of increasing children's interest in probability.

\section{ACKNOWLEDGMENTS}

This research was supported by Centro de Modelamiento Matemático (CMM), ACE210010, FB210005 BASAL, and Project FONDECYT 11150412, all financed by Chile's National Agency for Research and Development (ANID-Chile); by a collaboration agreement between the Ministry of Education of 
Chile and CMM (2014-2018); and by UNESCO-Hamdan Award and Unesco Chair "Preparing teachers to teach math in the 21 st century".

\section{REFERENCES}

Alvarado, H., Andaur, G., \& Estrada, A. (2018). Actitudes hacia la probabilidad y su enseñanza: un estudio exploratorio con profesores de Matemática en formación y ejercicio de Chile. [Attitudes towards probability and its teaching: An exploratory study with pre-service and in-service teachers of Mathematics] Revista Paradigma, 39(2), 36-64.

Auzmendi, E. (1992). Las actitudes hacia la matemática estadística en las enseñanzas medias y universitarias. [Attitudes towards statistical mathematics in secondary and higher education] Mensajeros.

Barrientos, O. (2010). La actitud científica ante la resolución de problemas matemáticos. [The scientific attitude to solving mathematical problems] Publicaciones del Instituto internacional de integración del convenio Andrés Bello.

Batanero, C. (2009). Retos para la formación estadística de los profesores. [Challenges for the statistical teacher training] Actas II Encontro de Probabilidade e Estatística na Scola. Universidade do Minho.

Batanero, C. (2013). La comprensión de la probabilidad en los niños. ¿Qué podemos aprender de la investigación? [The understanding of probability in children. What can we learn from research?] In J. A. Fernandes, P. F. Correia, M. H. Martinho \& F. Viseu, (Eds.), Atas do III Encontro de Probabilidades e Estatítica na Escola. Centro de Investigação em Educação.

Borovcnik, M. (1997). Fundamentale Ideen als Organisationsprinzip in der Mathematik-Didaktik [Fundamental ideas as an organising principle in the didactics of mathematics]. Schriftenreihe zur Didaktik der Mathematik der Österreichischen Mathematischen Gesellschaft (ÖMG), 27, 17-32.

Borovcnik, M. (2006). Probabilistic and statistical thinking. In M. Bosch (Ed.), Proceedings of the 4th Congress of the European Society for Research in Mathematics Education (pp. 484-506). ERME.

Borasi, R., Sheedy, J. R., \& Siegel, M. (1990). The power of stories in learning mathematics. Language Arts, 67(2), 174-189.

Braun, V., \& Clarke, V. (2006). Using thematic analysis in psychology. Qualitative Research in Psychology, 3(2), 77-101.

Brito, C., Guíñez, F., Salinas, R., Gálvez, G., Peet, T., \& Martínez, S. (2018). Alicia en el país de las probabilidades. [Alice in Randomland] Centro de Modelamiento Matemático. Universidad de Chile.

Carroll, L. (1865). Alice's adventures in wonderland. Boston International Pocket Library.

Cohen, L., Manion, L. \& Morrison, K. (2000). Research methods in education (5th ed.). Routledge Falmer.

Estrada, A. (2002). Análisis de las actitudes y conocimientos estadísticos elementales en la formación del profesorado. [Analysis of attitudes and elementary statistical knowledge in teacher training] (Doctoral dissertation, Universidad Autónoma de Barcelona).

Estrada, A., \& Batanero, C. (2015). Construcción de una escala de actitudes hacia la probabilidad y su enseñanza para profesores. [Construction of a scale of attitudes towards probability and its teaching for teachers]. In C. Fernández (Ed.), Actas del XIX Simposio de la Sociedad Española de Investigación en Educación Matemática, SEIEM (pp. 239-248). Alicante.

Estrada, A., \& Batanero, C. (2020). Prospective primary school teachers' attitudes towards probability and its teaching. International Electronic Journal of Mathematics Education, 15(1). https://doi.org/10.29333/iejme/5941

Estrada, A., Batanero, C., \& Lancaster, S. (2011). Teachers' attitudes towards statistics. In C. Batanero, G. Burrill, \& C. Reading (Eds.), Teaching statistics in school mathematics. Challenges for teaching and teacher education (pp. 173-174). Springer.

Estrada, A., Batanero, C., \& Díaz, C. (2018). Exploring teachers' attitudes towards probability and its teaching. In C. Batanero \& E. Chernoff, (Eds.), Teaching and learning stochastics: Advances in probability education research (pp. 313-332). Springer.

Estrada, A., Bazán, J., \& Aparicio, A. (2013). Evaluación de las propiedades psicométricas de una escala de actitudes hacia la estadística en profesores. [Evaluation of the psychometric properties of 
a scale of attitudes towards statistics in teachers] Avances de investigación en educación matemática, 3, 5-23.

Everitt, B. S. (1999). Chance rules: An informal guide to probability, risk, and statistics. Copemicus/Springer.

Gal, I. (2005). Towards "probability literacy" for all citizens. In G. Jones (Ed.), Exploring probability in school: Challenges for teaching and learning (pp. 43-71). Kluwer Academic Publishers.

Godino, J. D., Batanero, C., \& Cañizares, M. J. (1997). Azar y Probabilidad. Fundamentos didácticos y propuestas curriculares. [Chance and probability. Didactic foundations and curricular proposals.] Síntesis.

Groth, R., \& Meletiou-Mavrotheris, M. (2018). Research on statistics teachers' cognitive and affective characteristics. In D. Ben-Zvi, K. Makar \& J. Garfield (Eds.), International Handbook of Research in Statistics Education (pp. 327-355). Springer. https://doi.org/10.1007/978-3-319-66195-7_10

Heitele, D. (1975). An epistemological view on fundamental stochastic ideas. Educational Studies in Mathematics, 6(2), 187-205.

Hernández, R., Fernández, C., \& Baptista, P. (2002). Metodología de la investigación [Methodology of research]. México, DF: McGraw Hill. Interamericana Editores.

Kidd, P., \& Parshall, M. (2000). Getting the focus and the group: enhancing analytical rigor in focus group research. Qualitative Health Research, 10(3), 293-308.

Klinger, C. (2011). "Connectivism" a new paradigm for the mathematics anxiety challenge? Adults learning mathematics: An International Journal, 6(1), 7-19.

Lecoutre, M.-P. (1992). Cognitive models and problem spaces in "purely random" situations. Educational Studies in Mathematics, 23, 557-568.

MINEDUC. (2012). Bases Curriculares de Educación Básica (1 ${ }^{\mathrm{st}} \mathrm{ed}$.). [Curricular Basis of Basic Education] Santiago, Chile.

MINEDUC. (2016). Identificación de elementos críticos para fortalecer la formación de profesores en el área de matemática de Pedagogía en Educación Básica en Chile. [Identification of critical elements to strengthen primary school teacher training in the area of mathematics in Chile] CIAE \& CMM, Universidad de Chile. http://biblioteca.digital.gob.cl/handle/123456789/711

Morales, P. (1988). Medición de actitudes en psicología y educación $\left(1^{\text {st }}\right.$ ed.). [Measurement of attitudes in psychology and education.]. San Sebastián, Spain: Universidad de Comillas.

Ordóñez, X., Romero, S., \& Ruiz, C. (2016). Cuestionario de actitudes hacia la estadística (CAHE): Evidencias de validez y fiabilidad de las puntuaciones en una muestra de alumnos de educación. Bordón, 68(4), 121-136.

Scheaffer, R. L., Watkins, A. E., \& Landwehr, J. M. (1998). What every high-school graduate should know about statistics. In S. P. Lajoie (Ed.), Reflections on statistics: Learning, teaching and assessment in Grades K-I2 (pp. 3-31). Lawrence Erlbaum.

Schoenfeld, A. (1989). Explorations of students' mathematical beliefs and behavior. Journal for Research in Mathematics Education, 11, 148-149.

Strauss, A., \& Corbin, J. (2007). Basics of qualitative research. SAGE Publications.

Tan, C. K., Harji, M. B., \& Lau, S. H. (2011). Fostering positive attitude in probability learning using graphing calculator. Computers \& Education, 57(3), 2011-2024. https://doi.org/10.1016/j.compedu.2011.05.005

Vásquez, C. (2014). Evaluación de los conocimientos didáctico-matemáticos para la enseñanza de la probabilidad de los profesores de educación primaria en active. [Assessment of didacticmathematical knowledge for the teaching of probability of active primary education teachers] (Doctoral thesis, Universidad de Girona, Girona).

Vásquez, C., Alvarado, H., \& Ruz, F. (2019). Actitudes de futuras maestras de Educación Infantil hacia la estadística, la probabilidad y su enseñanza. [Attitudes of future teachers of early dhildhood towards statistics, probability and their teaching] Revista Educación Matemática, 31(3), 177-202. https://doi.org/10.24844/EM3103.07

Veloo, A., \& Chairhany, S. (2013). Fostering students' attitudes and achievement in probability using teams-games-tournaments. Procedia - Social and Behavioral Sciences, 93, 59-64. 


\section{APPENDIX}

Scale of Attitudes Towards Probability and Its Teaching (Estrada, Batanero, \& Díaz, 2018; Estrada \& Batanero, 2020).

1: strongly disagree, 2: disagree, 3 : neither agree nor disagree, 4: disagree, and 5: strongly agree.

\begin{tabular}{|c|c|c|c|c|c|}
\hline Item & 1 & 2 & 3 & 4 & 5 \\
\hline 1. I enjoy the lessons in which probability is explained & & & & & \\
\hline 2. I use probability information when making decisions & & & & & \\
\hline 3. It will be hard for me to teach probability & & & & & \\
\hline 4. Probability helps you understand today's world & & & & & \\
\hline 5. I like probability; it is a subject that always interested me & & & & & \\
\hline 6. Probability is easy & & & & & \\
\hline 7. I never used probability outside mathematics & & & & & \\
\hline 8. I have mastered the main contents of probability & & & & & \\
\hline 9. I am sure I will enjoy teaching probability in school & & & & & \\
\hline $\begin{array}{l}\text { 10. I think I can notice and correct students' errors and } \\
\text { difficulties with probability }\end{array}$ & & & & & \\
\hline $\begin{array}{l}\text { 11. I will only teach probability if there is time available after } \\
\text { teaching the other topics }\end{array}$ & & & & & \\
\hline 12. Probability is only useful for games of chance & & & & & \\
\hline 13. Probability is not as valuable as other areas of mathematics & & & & & \\
\hline $\begin{array}{l}\text { 14. It will be easy for me to design assessment tasks related to } \\
\text { probability }\end{array}$ & & & & & \\
\hline 15. I use probability in everyday life & & & & & \\
\hline 16. I feel scared when faced with probability information & & & & & \\
\hline 17. Probability is understandable only to "science people" & & & & & \\
\hline $\begin{array}{l}\text { 18. I avoid reading information that contains probability terms } \\
\text { (e.g., in drugs prospects) }\end{array}$ & & & & & \\
\hline 19. Probability knowledge helps students to reason critically & & & & & \\
\hline 20. Probability should be taught since the first teaching levels & & & & & \\
\hline $\begin{array}{l}\text { 21. I feel worried about being able to reply to my students' } \\
\text { questions about probability }\end{array}$ & & & & & \\
\hline $\begin{array}{l}\text { 22. I do not feel well enough prepared to solve any basic } \\
\text { probability problem }\end{array}$ & & & & & \\
\hline $\begin{array}{l}\text { 23. I would not be able to prepare suitable didactic resources for } \\
\text { the probability lesson }\end{array}$ & & & & & \\
\hline
\end{tabular}




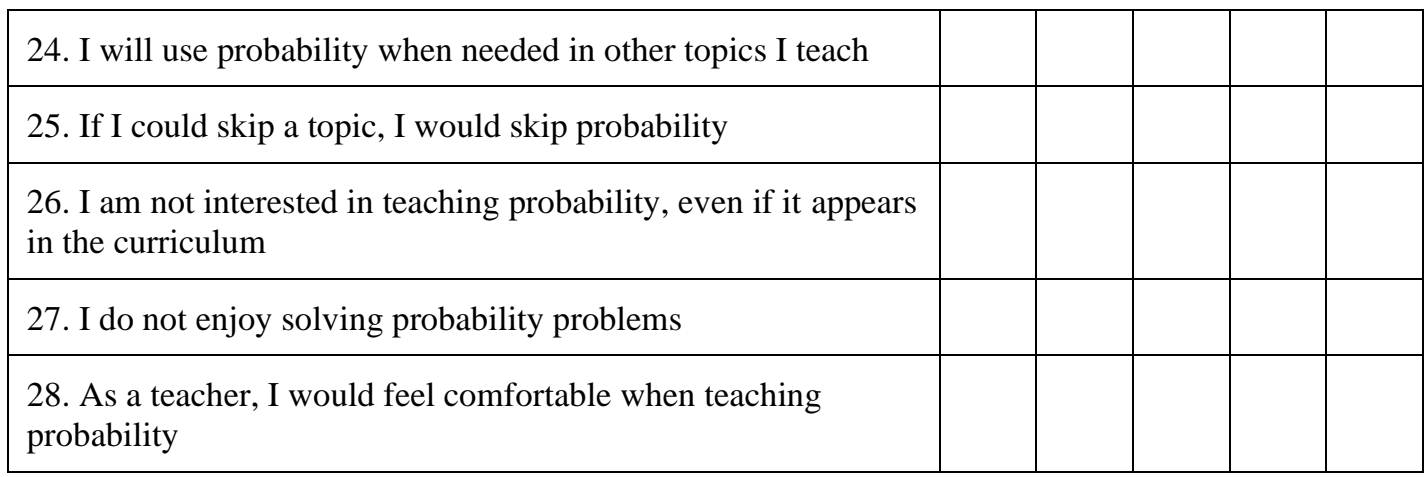

FLAVIO GUIÑEZ

Center for Mathematical Modeling Facultad de Ciencias Físicas y Matemáticas Beauchef 851, Edificio Norte - Piso 7, Santiago, Chile 